\title{
Quality Characteristics of Frozen Broiler Breast Meat Pretreated with Increasing Concentrations of Sodium Chloride
}

\author{
Massimiliano Petracci ${ }^{1}$, Simone Rimini ${ }^{1}$, Roel W.A.W. Mulder ${ }^{2}$ and Claudio Cavani ${ }^{1}$ \\ ${ }^{1}$ Department of Agricultural and Food Sciences and Technologies, Alma Mater Studiorum \\ - University of Bologna, 47521 Cesena (FC), Italy \\ ${ }^{2}$ Spelderholt Poultry Consulting and Research, NL-8162 CW Epe, The Netherlands
}

\begin{abstract}
A study was conducted in order to investigate quality traits and sensory properties of frozen broiler breast meat pretreated with increasing concentration (from 0 to $2 \%$ ) of sodium chloride (salt). Meat samples were obtained in a single major commercial processing plant from a homogenous flock of chicken broilers (Cobb strain, 44 days-old, mixed sex, average live weight of $2.55 \mathrm{~kg}$ ). Whole breasts were collected at random immediately after chilling and fillets (P. major muscles) were deboned by hand. A total of 12 groups of fillets were subsequently salted by hand with $0.0,0.2,0.4,0.5,0.6,0.8,1.0,1.2,1.4,1.6,1.8,2.0 \%$ of sodium chloride, packaged in bags, quickly frozen in the processing plant and stored at $-24^{\circ} \mathrm{C}$ for 3 months. Prior to analysis, fillets were thawed at $2-4^{\circ} \mathrm{C}$ for $72 \mathrm{~h}$ and 12 fillets per group were used to determine chemical-physical characteristics ( $\mathrm{pH}$, colour, and sodium chloride content), functional properties (drip loss, cooking loss on raw and minced meat, AK-shear force, TBARS analysis) and sensory traits (level of tenderness, level of juiciness and overall liking).

The addition of salt determined significant modifications of overall chemico-physical traits of the meat with special regards to $\mathrm{pH}$, colour, water holding capacity and texture. Increased levels of salt determined a higher $\mathrm{pH}$, darker colour, superior water holding capacity (assessed by drip and cooking losses), and higher tenderness (lower AK-shear values). The maximum improvement of water holding capacity was observed for salt level higher than $1.2 \%$. Inclusion of salt up to $2 \%$ did not exert a negative effect on lipid peroxidation. Sensory test evidenced higher scores of overall preference of meat starting from $0.8 \%$ salt concentration; highest scores of tenderness, juiciness and overall preference in meat samples with high salt content (1.6 and $2.0 \%$ groups) were observed.
\end{abstract}

Key words: breast meat, broiler, freezing, quality traits, sodium chloride

J. Poult. Sci., 50: 396-401, 2013

\section{Introduction}

In the past decades, worldwide poultry meat production and consumption have increased rapidly and, in many parts of the world, per capita consumption of poultry meat will continue to grow. Within this context, market share of processed poultry meat products has been a dramatic increase during the last decades (Cavani et al., 2009). With the current state of the market, freezing has come to play a tremendous role to both store and trade of raw materials (i.e. deboned, chunked, ground or mechanically separated meats) and marketing and as preservation system for the more expensive value-added products (i.e. entrées, ready-to-eat foods, etc.). Indeed frozen storage constitutes the most ef-

Received: November 27, 2012, Accepted: January 25, 2013

Released Online Advance Publication: March 25, 2013

Correspondence: Dr. M. Petracci, Department of Agricultural and Food Sciences and Technologies, Alma Mater Studiorum - University of Bologna, 47521 Cesena (FC), Italy. (E-mail: m.petracci@unibo.it) fective means of maintaining high-quality and safe poultry products during storage for producers, distributors, catering and final consumers (Fletcher, 2004; Kotrola and Mohyla, 2011). Before freezing, for commercial or quality reasons, poultry meat can be added with sodium chloride (salt). Salt is the most important ingredient in the production of meat and poultry products by providing three major functions: i) assist in protein solubilising with beneficial effect on water binding ability and texture; ii) alter microbial growth; iii) enhance and provide flavour (Barbut, 2002). The theory about sodium chloride improving water holding capacity (WHC) of meat products has been reviewed by Offer and Knight (1988), Ruusunen and Puolanne (2005) and Cheng and Sun (2008). In solution, sodium chloride separates into sodium $\left(\mathrm{Na}^{+}\right)$and chloride $(\mathrm{Cl}-)$ ions, however the effect on meat proteins is most likely caused by the fact that $\mathrm{Cl}$ - ions are more strongly bound to the proteins that the $\mathrm{Na}^{+}$ions (Sebranek, 2009). Chloride ions tend to bind to the thick (myosin) and thin (actin) filaments and increase the elec- 
trostatic repulsive forces between them. With increasing the repulsive forces, the protein structure matrix unfolds, the gaps between actin and myosin increase and then transverse swelling occurs (Offer and Trinick, 1983; Hamm, 1986). Moreover the adsorption of $\mathrm{Cl}$ - ions with positively charged groups of myosin results in a shift of the isoelectric point towards a more acidic $\mathrm{pH}$ value. As a result, increased levels of water can be bound without changing the $\mathrm{pH}$ value of the meat itself, as the shift of the isoelectric point from 5.2 to 5.0 widens the gap between $\mathrm{pH}$ values present in the meat and the isoelectric point. A larger gap between the two $\mathrm{pH}$ values increases the capillary effect of the muscle fibres and an increased capillary effect improves water-binding potential in intact meat and entrapment of extraneous water in processed meat (Feiner, 2006). A salt concentration of 1.0$1.6 \%$ can be considered the most widely used in poultry meat formulations. In recent decades, with the increasing consumption of many different processed foods containing high level of sodium, the perception of dietary salt has evolved to a point where it is now considered, by some, to be a potential health threat. Many processed foods contain high levels of salt and several countries have developed national programs for significantly reducing the sodium chloride content in many processed foods and encouraging a decrease in discretionary salt use (Doyle and Glass, 2010). It is estimated that cured and processed meat contribute just over $20 \%$ of the daily sodium intake for adults in the USA, Ireland and the UK (Desmond, 2006). Therefore, the addition of sodium chloride during meat processing should be restricted as little is possible (Ruusunen and Poulanne, 2005; Desmond, 2006).

Influence of freezing on meat quality properties has been largely investigated over the years (James and James, 2002), however little information are available on quality of frozen meat pretreated with sodium chloride. The aim of this study was to investigate quality traits and sensory properties of frozen broiler breast meat pretreated with increasing concentration of sodium chloride (from 0 to $2 \%$ ).

\section{Materials and Methods}

\section{Experimental Procedures}

Meat samples were obtained in a single major commercial processing plant from a homogenous flock of chicken broilers (Cobb strain, age 44 days, mixed sex, average weight of $2.55 \mathrm{~kg}$ ). Whole breasts were collected at random immediately after chilling and fillets (P. major muscles) were deboned by hand. A total of 12 groups of fillets were subsequently salted by hand with $0.0,0.2,0.4,0.5,0.6,0.8,1.0$, $1.2,1.4,1.6,1.8,2.0 \%$ of sodium chloride, packaged in bags weighing $7.5 \mathrm{~kg}$, quickly frozen in the processing plant and subsequently delivered under freezing conditions for subsequent analysis. After frozen storage at $-24^{\circ} \mathrm{C}$ for 3 months, fillets were thawed at $2-4^{\circ} \mathrm{C}$ for $72 \mathrm{~h}$ and used the following analysis. Twelve of them for each group were kept intact and used to assess colour, $\mathrm{pH}$, drip loss, cooking loss and shear force after cooking, while other 12 sample/group were individually ground and analyzed for cooking loss on a meat patty, sodium chloride content and TBARS. The remaining samples from $0.0,0.4,0.8,1.2,1.6$ and $2.0 \%$ groups were used to perform sensory analysis.

\section{Analytical Methods}

Colour measurement. The CIE (1978) system colour profile of lightness $\left(\mathrm{L}^{*}\right)$, redness $\left(\mathrm{a}^{*}\right)$, and yellowness $\left(\mathrm{b}^{*}\right)$ was measured by a reflectance colorimeter (Minolta Chroma Meter CR-400, Minolta Italia S.p.A., Milano, Italy) using illuminant source $\mathrm{C}$. The colorimeter was calibrated throughout the study using a standard white ceramic tile (reference number 1353123; $\mathrm{Y}=92.7, \mathrm{x}=0.3133$, and $\mathrm{y}=0.3193$ ). Colour was measured on the cranial, medial surface (bone side) in an area free of colour defects (bruises, discolorations, haemorrhages, full blood vessels, picking damage, or any other condition which may have affected uniform color reading) on intact fillets before and after cooking (Petracci and Baeza, 2011).

pH Measurement. The $\mathrm{pH}$ was determined using a modification of the iodoacetate method initially described by Jeacocke (1977). Approximately $2.5 \mathrm{~g}$ of breast meat was removed from the cranial end of each fillet, minced by hand, homogenized in $25 \mathrm{~mL}$ of a $5 \mathrm{mM}$ iodoacetate solution with $150 \mathrm{mM}$ potassium chloride for $30 \mathrm{~s}$, and the $\mathrm{pH}$ of the homogenate was determined using a $\mathrm{pH}$ meter calibrated at $\mathrm{pH} 4.0$ and 7.0 equipped with 924001 electrode (Bibby Scientific Ltd, T/As Jenway, Essex, UK)

Drip loss determination. Each fillet was individually weighed and suspended in a plastic box at $2-4^{\circ} \mathrm{C}$. After 48 hours, fillets were blotted for the excess surface fluids, reweighed, and drip loss determined as percentage of weight lost by the sample during refrigerated storage period (Petracci and Baeza, 2011).

Cooking loss determination. Raw Meat. Each fillet was individually weighed and cooked in a convection oven on aluminum trays at $180^{\circ} \mathrm{C}$ until $80^{\circ} \mathrm{C}$ at core sample. The fillets were then allowed to equilibrate to room temperature, re-weighed, and cooking loss determined as percentage of weight lost by the sample. Ground meat patties. Cooking loss on meat patties, was determined by exactly individually weighing and cooking the patties $(70 \mathrm{~g} ; 8.5 \mathrm{~cm}$ diameter and $1.5 \mathrm{~cm}$ thickness) on a convention oven at $180^{\circ} \mathrm{C}$ until $80^{\circ} \mathrm{C}$ at core sample. The samples were then allowed to equilibrate to room temperature, reweighed, and cooking loss determined as percentage of weight lost by the sample.

Shear value determination. Shear values were determined using an TA.HDi Heavy Duty texture analyzer (Stable Micro Systems Ltd., Godalming, Surrey, UK) equipped with an Allo-Kramer shear cell using the procedure described by Sams et al. (1990). Two meat samples (approximately $2 \times 4$ $\times 1 \mathrm{~cm}$ ) from the cranial portion of each intact fillet after cooking were cut parallel with the muscle fiber direction, weighed, and sheared with the blades at a right angle to the fibers using a $250 \mathrm{~kg}$ load cell and cross head speed of 500 $\mathrm{mm} / \mathrm{min}$. Shear values are reported as kilograms shear per gram of sample.

TBARS analysis. The susceptibility of muscle tissue homogenates to iron-induced lipid oxidation was determined according to the method of Kornbrust and Mavis (1980). 
Table 1. Numerical-hedonic scales used to the panellists to score the meat samples during sensory analysis

\begin{tabular}{|c|c|c|}
\hline Level of tenderness & Level of juiciness & Overall liking \\
\hline 8 - Extremely tender & 8 - Extremely juicy & 5 - Like very much \\
\hline 7 - Very tender & 7 - Very juicy & 4 - Like moderately \\
\hline 6 - Moderately tender & 6 - Moderately juicy & 3 - Neither like nor dislike \\
\hline 5 - Slightly tender & 5 - Slightly juicy & 2 - Dislike moderately \\
\hline 4 - Slightly tough & 4 - Slightly dry & 1 - Dislike very much \\
\hline 3 - Moderately tough & 3 - Moderately dry & \\
\hline $2-$ Very tough & 2 - Very dry & \\
\hline 1 - Extremely tough & 1 - Extremely dry & \\
\hline
\end{tabular}

Tubes containing $100 \mu l$ of homogenates were incubated at $37^{\circ} \mathrm{C}$ and removed at fixed time intervals $(0,30,60,90$, and $150 \mathrm{~min}$ ) for measurement of 2-thiobarbituric acid-reactive substances (TBARS). Protein content of the meat was determined according to the Lowry procedure (Lowry et al., 1951) and TBARS expressed as nmoles malonaldehyde (MDA)/mg protein.

Sodium chloride content. Each fillet was finely ground and an aliquot of $10 \mathrm{~g}$ was used to determine sodium chloride content in duplicate volumetric method (AOAC, 1995). Sodium chloride content is reported as percentage.

Consumer sensory test. Six products $(0.0,0.4,0.8,1.2$, $1.6,2.0 \%$ of sodium chloride) were chosen and consumer test was conducted in a certified sensory laboratory (ISO, 1989) using 44 untrained panelists. Demographic characteristics for the consumer panelists were as follows: $48 \%$ males, $52 \%$ females; $84 \% 20$ to $30 \mathrm{yr}$ old, $11 \% 30$ to $40 \mathrm{yr}$ old, and $5 \%>40$ yr old. Each panelist was offered 6 warm samples (1 for each group) according to a randomized block design and asked to score each sample for tenderness, ranking from 1 (extremely tough) to 8 (extremely tender), for juiciness, ranking from 1 (extremely dry) to 8 (extremely juicy) and overall liking from 1 (dislike very much) to 5 (like very much) (Tab. 1).

\section{Statistical Analysis}

Data were analyzed using the ANOVA option of the general linear models (GLM) procedure of SAS $^{\circledR}$ software (SAS Institute, 1988) testing the salt group as main effect. Means were separated using Duncan multiple range test option of the GLM procedure (SAS Institute, 1988).

\section{Results and Discussion}

The sodium chloride content, $\mathrm{pH}$ values, drip loss, cooking loss of intact and ground meat and AK-shear force from the twelve groups are presented in Table 2. As expected, the addition of sodium chloride (from 0 to $2 \%$ ) determined a significant $(P<0.01)$ increasing of sodium chloride content of the meat. The variability within each group was very low, this means that procedures for adding salt were effective.

Overall the addition of sodium chloride determined a significant $(P<0.01)$ increasing of breast meat $\mathrm{pH}$ (from 5 . 73 to 6.03 ). A significant effect of salt addition on $\mathrm{pH}$ was detected already at $0.2 \%$. It is well established that the use of sodium chloride does not exert relevant effect on meat $\mathrm{pH}$ (Shults and Wierbicki, 1973; Sheard and Tali, 2004; Petracci et al., 2012) so this result should be related to the different liquid losses observed during thawing (data not shown). In fact, thaw losses were very high in control group (11.9\%), while increased percentages of salt determined an enormous reduction of these losses. Indeed, Leygonie et al. (2012) suggested that freezing with subsequent exudate production could cause denaturation of buffering compounds (e.g. proteins, anserine, carnosine), the release of hydrogen ions and a subsequent decrease in $\mathrm{pH}$. The same authors also hypothesized that the loss of fluid from the meat tissue following thawing may cause an increase in the concentration of the solutes, which results in a decrease in the $\mathrm{pH}$ (Leygonie et al., 2012).

The measurement of drip loss showed a significant $(P<$ $0.01)$ effect of salt addition. A significant $(P<0.05)$ effect of salt addition on drip loss was detected starting from $0.4 \%$. In particular, drip loss range was $0.86-0.97 \%$ in samples with salt addition from 0.4 to $1.0 \%$, while lower $(P<0.05)$ drip losses $(0.59-0.63 \%)$ values were observed when salt addition was higher than $1.0 \%$.

The determination of weight loss of intact fillets during cooking evidenced that addition of salt concentration higher than $0.2 \%$ determined a significant reduction of weight loss during cooking. This decreasing trend was quite linear going from 0.4 to $2.0 \%$ group. The cooking losses measured on ground breast meat (patties) evidenced a similar trend, however the extent of losses reduction in consequences of salt addition was higher: the reduction from cooking loss observed in control group and $2.0 \%$ group was about of $14 \%$. These results confirm that gradually increasing salt level up to $2 \%$ increase the ability of meat to retain its own liquids during storage and cooking (Shults and Wierbicki, 1973; Swatland and Barbut, 1999). As mentioned before, the addition of salt to the meat has the effect to solubilize myofibrillar proteins (actin and myosin) and adding more negative chloride ions to the system (Offer and Trinick, 1983; Hamm, 1986). Both effects determined an increased water holding capacity of the meat. Moreover, during cooking, the extracted proteins coagulate and provide binding of meat particles, bind moisture (minimize cooking losses) and form a coherent matrix to hold the melting meat fat (Barbut, 
Table 2. Effect of added sodium chloride level on salt content, pH, drip loss, cook loss on raw meat and meat patties, and AK shear force of broiler breast meat (mean \pm SEM) ( $n=12$ samples/group)

\begin{tabular}{ccccccc}
\hline \hline $\begin{array}{c}\text { Added salt } \\
(\%)\end{array}$ & $\begin{array}{c}\text { Salt content } \\
(\%)\end{array}$ & $\mathrm{pH}$ & Drip loss $(\%)$ & $\begin{array}{c}\text { Cook loss on } \\
\text { raw meat }(\%)\end{array}$ & $\begin{array}{c}\text { Cook loss on } \\
\text { meat patties }(\%)\end{array}$ & $\begin{array}{c}\text { AK-shear } \\
\text { value }(\mathrm{kg} / \mathrm{g})\end{array}$ \\
\hline 0.0 & $0.21 \pm 0.01 \mathrm{a}$ & $5.73 \pm 0.02 \mathrm{a}$ & $1.42 \pm 0.08 \mathrm{~d}$ & $19.7 \pm 0.34 \mathrm{f}$ & $25.5 \pm 0.60 \mathrm{~d}$ & $5.39 \pm 0.58 \mathrm{~b}$ \\
0.2 & $0.43 \pm 0.01 \mathrm{~b}$ & $5.85 \pm 0.02 \mathrm{~b}$ & $1.42 \pm 0.07 \mathrm{~d}$ & $19.1 \pm 0.23 \mathrm{f}$ & $24.5 \pm 0.63 \mathrm{~d}$ & $3.28 \pm 0.32 \mathrm{a}$ \\
0.4 & $0.43 \pm 0.01 \mathrm{~b}$ & $5.87 \pm 0.02 \mathrm{bc}$ & $0.97 \pm 0.04 \mathrm{c}$ & $16.8 \pm 0.26 \mathrm{de}$ & $19.7 \pm 0.90 \mathrm{c}$ & $3.46 \pm 0.31 \mathrm{a}$ \\
0.5 & $0.58 \pm 0.01 \mathrm{c}$ & $5.89 \pm 0.02 \mathrm{bcd}$ & $0.93 \pm 0.08 \mathrm{c}$ & $16.7 \pm 0.29 \mathrm{cde}$ & $18.1 \pm 0.49 \mathrm{c}$ & $3.26 \pm 0.31 \mathrm{a}$ \\
0.6 & $0.63 \pm 0.01 \mathrm{~d}$ & $5.92 \pm 0.02 \mathrm{cde}$ & $0.96 \pm 0.10 \mathrm{c}$ & $17.0 \pm 0.25 \mathrm{e}$ & $19.6 \pm 0.78 \mathrm{c}$ & $2.91 \pm 0.22 \mathrm{a}$ \\
0.8 & $0.81 \pm 0.01 \mathrm{e}$ & $5.90 \pm 0.02 \mathrm{bcd}$ & $0.80 \pm 0.06 \mathrm{bc}$ & $16.4 \pm 0.21 \mathrm{bcde}$ & $14.0 \pm 0.60 \mathrm{~b}$ & $2.81 \pm 0.15 \mathrm{a}$ \\
1.0 & $0.97 \pm 0.01 \mathrm{f}$ & $5.93 \pm 0.02 \mathrm{de}$ & $0.86 \pm 0.06 \mathrm{c}$ & $16.8 \pm 0.31 \mathrm{de}$ & $13.3 \pm 0.40 \mathrm{~b}$ & $2.89 \pm 0.13 \mathrm{a}$ \\
1.2 & $1.14 \pm 0.01 \mathrm{~g}$ & $5.96 \pm 0.02 \mathrm{ef}$ & $0.63 \pm 0.06 \mathrm{ab}$ & $16.1 \pm 0.29 \mathrm{bcd}$ & $11.0 \pm 0.58 \mathrm{a}$ & $2.98 \pm 0.14 \mathrm{a}$ \\
1.4 & $1.39 \pm 0.03 \mathrm{~h}$ & $6.00 \pm 0.01 \mathrm{fg}$ & $0.55 \pm 0.04 \mathrm{a}$ & $16.3 \pm 0.31 \mathrm{bcde}$ & $12.4 \pm 0.43 \mathrm{ab}$ & $2.89 \pm 0.12 \mathrm{a}$ \\
1.6 & $1.49 \pm 0.02 \mathrm{i}$ & $5.99 \pm 0.01 \mathrm{fg}$ & $0.67 \pm 0.03 \mathrm{ab}$ & $15.6 \pm 0.27 \mathrm{ab}$ & $10.9 \pm 0.77 \mathrm{a}$ & $3.27 \pm 0.19 \mathrm{a}$ \\
1.8 & $1.51 \pm 0.03 \mathrm{i}$ & $5.99 \pm 0.01 \mathrm{fg}$ & $0.64 \pm 0.06 \mathrm{ab}$ & $15.9 \pm 0.26 \mathrm{abc}$ & $10.6 \pm 0.69 \mathrm{a}$ & $2.82 \pm 0.12 \mathrm{a}$ \\
2.0 & $1.66 \pm 0.03 \mathrm{k}$ & $6.03 \pm 0.01 \mathrm{~g}$ & $0.59 \pm 0.03 \mathrm{a}$ & $15.1 \pm 0.21 \mathrm{a}$ & $11.3 \pm 0.47 \mathrm{a}$ & $3.12 \pm 0.15 \mathrm{a}$ \\
\hline Probability & $<0.001$ & $<0.001$ & $<0.001$ & $<0.001$ & $<0.001$ & $<0.001$ \\
\hline
\end{tabular}

Means with different letters on the same column within the same effect differ significantly $(P<0.05)$.

Table 3. Effect of added sodium chloride level on colour of raw and cooked broiler breast meat $(\operatorname{mean} \pm \operatorname{SEM})(n=$ 12 samples/group)

\begin{tabular}{ccccccc}
\hline \hline $\begin{array}{c}\text { Added salt } \\
(\%)\end{array}$ & $\begin{array}{c}\text { Lightness } \\
\left(\mathrm{L}^{*}\right)\end{array}$ & $\begin{array}{c}\text { Colour of raw meat } \\
\text { Redness } \\
\left(\mathrm{a}^{*}\right)\end{array}$ & $\begin{array}{c}\text { Yellowness } \\
\left(\mathrm{b}^{*}\right)\end{array}$ & $\begin{array}{c}\text { Lightness } \\
\left(\mathrm{L}^{*}\right)\end{array}$ & $\begin{array}{c}\text { Colour of cooked meat } \\
\text { Redness } \\
\left(\mathrm{a}^{*}\right)\end{array}$ & $\begin{array}{c}\text { Yellowness } \\
\left(\mathrm{b}^{*}\right)\end{array}$ \\
\hline 0.0 & $55.7 \pm 0.44 \mathrm{f}$ & $1.04 \pm 0.17$ & $10.73 \pm 0.32 \mathrm{e}$ & $81.7 \pm 0.43 \mathrm{c}$ & $1.75 \pm 0.14 \mathrm{def}$ & $17.5 \pm 0.34 \mathrm{~cd}$ \\
0.2 & $53.3 \pm 0.44 \mathrm{e}$ & $0.98 \pm 0.17$ & $8.80 \pm 0.34 \mathrm{~cd}$ & $81.3 \pm 0.40 \mathrm{bc}$ & $1.51 \pm 0.10 \mathrm{abcde}$ & $16.3 \pm 0.29 \mathrm{ab}$ \\
0.4 & $51.5 \pm 0.53 \mathrm{~d}$ & $1.22 \pm 0.16$ & $8.56 \pm 0.47 \mathrm{~cd}$ & $81.9 \pm 0.29 \mathrm{c}$ & $1.78 \pm 0.07 \mathrm{f}$ & $16.1 \pm 0.39 \mathrm{ab}$ \\
0.5 & $50.8 \pm 0.50 \mathrm{~d}$ & $1.60 \pm 0.20$ & $8.41 \pm 0.42 \mathrm{~cd}$ & $81.3 \pm 0.38 \mathrm{bc}$ & $1.21 \pm 0.10 \mathrm{a}$ & $17.0 \pm 0.42 \mathrm{abc}$ \\
0.6 & $50.9 \pm 0.48 \mathrm{~d}$ & $1.52 \pm 0.17$ & $9.21 \pm 0.33 \mathrm{~d}$ & $81.0 \pm 0.43 \mathrm{bc}$ & $1.38 \pm 0.11 \mathrm{abc}$ & $18.3 \pm 0.44 \mathrm{~d}$ \\
0.8 & $49.0 \pm 0.51 \mathrm{c}$ & $1.37 \pm 0.17$ & $8.71 \pm 0.32 \mathrm{~cd}$ & $81.4 \pm 0.38 \mathrm{bc}$ & $1.57 \pm 0.11 \mathrm{bcdef}$ & $16.5 \pm 0.25 \mathrm{abc}$ \\
1.0 & $49.2 \pm 0.54 \mathrm{c}$ & $1.31 \pm 0.23$ & $9.04 \pm 0.37 \mathrm{~d}$ & $81.0 \pm 0.47 \mathrm{bc}$ & $1.43 \pm 0.15 \mathrm{abcd}$ & $16.6 \pm 0.44 \mathrm{abc}$ \\
1.2 & $47.5 \pm 0.60 \mathrm{~b}$ & $0.93 \pm 0.11$ & $7.85 \pm 0.35 \mathrm{bc}$ & $80.3 \pm 0.39 \mathrm{ab}$ & $1.71 \pm 0.08 \mathrm{cdef}$ & $16.5 \pm 0.34 \mathrm{abc}$ \\
1.4 & $47.7 \pm 0.37 \mathrm{~b}$ & $1.00 \pm 0.14$ & $6.84 \pm 0.44 \mathrm{ab}$ & $80.3 \pm 0.36 \mathrm{ab}$ & $1.18 \pm 0.10 \mathrm{a}$ & $17.4 \pm 0.61 \mathrm{bcd}$ \\
1.6 & $47.3 \pm 0.44 \mathrm{~b}$ & $1.25 \pm 0.21$ & $6.18 \pm 0.21 \mathrm{a}$ & $80.7 \pm 0.27 \mathrm{bc}$ & $1.66 \pm 0.13 \mathrm{cdef}$ & $15.8 \pm 0.14 \mathrm{a}$ \\
1.8 & $47.3 \pm 0.37 \mathrm{~b}$ & $1.12 \pm 0.20$ & $7.26 \pm 0.28 \mathrm{ab}$ & $79.4 \pm 0.29 \mathrm{a}$ & $1.32 \pm 0.11 \mathrm{ab}$ & $17.3 \pm 0.37 \mathrm{bcd}$ \\
2.0 & $45.9 \pm 0.51 \mathrm{a}$ & $1.25 \pm 0.16$ & $6.37 \pm 0.38 \mathrm{a}$ & $79.5 \pm 0.30 \mathrm{a}$ & $1.87 \pm 0.06 \mathrm{f}$ & $16.5 \pm 0.37 \mathrm{abc}$ \\
\hline Probability & $<0.001$ & 0.146 & $<0.001$ & $<0.001$ & $<0.001$ & $<0.001$
\end{tabular}

Means with different letters on the same column within the same effect differ significantly $(P<0.05)$.

2002). However, this positive effect on WHC is also due to the increasing in meat $\mathrm{pH}$ observed in groups going from 0.0 to $2.0 \%$. This shift of $\mathrm{pH}$ towards higher values determined a greater negative net charge in meat proteins by increasing the WHC of the meat (Feiner, 2006). So the increase of WHC observed in this study can be explained by the concomitant effect of salt addition and $\mathrm{pH}$ increase (Petracci et al., 2004).

The instrumental determination of tenderness (AK-shear force) of cooked meat showed a significant $(P<0.05)$ higher value of shear force in control group if compared with salt treated groups which did not differ from each others. Lee et al. (2008) found that long-term storage of unsalted broiler breast meat decreases meat tenderness. Present findings demonstrated that just a slight addition of salt is able to determine an improvement of meat tenderness confirming the previous finding of Swatland and Barbut (1999) by preventing meat toughening caused by long-term freezing.

The colour of raw and cooked broiler breast meat is reported in Table 3. The measurements of colour on raw meat evidenced a significant effect $(P<0.01)$ on lightness $\left(\mathrm{L}^{*}\right)$ and yellowness $\left(b^{*}\right)$ coordinates, while redness $\left(a^{*}\right)$ was not influenced by the experimental effect. The addition of sodium chloride ( 0 to $2 \%$ ) determined a significant $(P<0.01)$ decreasing of lightness ( $\mathrm{L}^{*} ; 55.7$ to 45.9 ) and yellowness $\left(b^{*} ; 10.7\right.$ to 6.4$)$ values. This means that salt addition determined a darker and less yellow colour of the breast. A significant effect of salt addition on lightness and yellowness 
Table 4. Effect of added sodium chloride level on lipid susceptibility (TBARS) of broiler breast meat (mean \pm SEM) ( $n=12$ samples/group)

\begin{tabular}{ccccccc}
\hline \hline $\begin{array}{c}\text { Added salt } \\
(\%)\end{array}$ & 0 min & $30 \mathrm{~min}$ & $60 \mathrm{~min}$ & $90 \mathrm{~min}$ & $120 \mathrm{~min}$ & $150 \mathrm{~min}$ \\
\hline 0.0 & $0.279 \pm 0.070$ & $0.622 \pm 0.057$ & $0.825 \pm 0.113$ & $0.908 \pm 0.145$ & $1.033 \pm 0.154$ & $1.194 \pm 0.193$ \\
0.2 & $0.249 \pm 0.024$ & $0.541 \pm 0.046$ & $0.663 \pm 0.050$ & $0.854 \pm 0.070$ & $1.050 \pm 0.090$ & $1.228 \pm 0.199$ \\
0.4 & $0.189 \pm 0.025$ & $0.642 \pm 0.097$ & $0.844 \pm 0.112$ & $1.038 \pm 0.134$ & $1.266 \pm 0.175$ & $1.454 \pm 0.160$ \\
0.5 & $0.283 \pm 0.055$ & $0.593 \pm 0.120$ & $0.963 \pm 0.138$ & $1.180 \pm 0.191$ & $1.372 \pm 0.190$ & $1.600 \pm 0.262$ \\
0.6 & $0.252 \pm 0.036$ & $0.740 \pm 0.202$ & $1.114 \pm 0.267$ & $1.279 \pm 0.303$ & $1.484 \pm 0.278$ & $1.786 \pm 0.347$ \\
0.8 & $0.217 \pm 0.022$ & $0.777 \pm 0.034$ & $1.037 \pm 0.049$ & $1.185 \pm 0.101$ & $1.368 \pm 0.147$ & $1.562 \pm 0.191$ \\
1.0 & $0.220 \pm 0.026$ & $0.544 \pm 0.145$ & $0.667 \pm 0.150$ & $0.995 \pm 0.172$ & $1.133 \pm 0.166$ & $1.446 \pm 0.173$ \\
1.2 & $0.259 \pm 0.033$ & $0.862 \pm 0.143$ & $1.315 \pm 0.220$ & $1.444 \pm 0.214$ & $1.472 \pm 0.212$ & $1.592 \pm 0.221$ \\
1.4 & $0.235 \pm 0.031$ & $0.498 \pm 0.067$ & $0.796 \pm 0.110$ & $1.181 \pm 0.159$ & $1.526 \pm 0.285$ & $1.709 \pm 0.295$ \\
1.6 & $0.231 \pm 0.022$ & $0.640 \pm 0.144$ & $1.028 \pm 0.174$ & $1.254 \pm 0.220$ & $1.439 \pm 0.230$ & $1.614 \pm 0.285$ \\
1.8 & $0.225 \pm 0.031$ & $0.584 \pm 0.095$ & $1.013 \pm 0.160$ & $1.381 \pm 0.201$ & $1.512 \pm 0.221$ & $1.796 \pm 0.265$ \\
2.0 & $0.255 \pm 0.051$ & $0.569 \pm 0.077$ & $0.824 \pm 0.122$ & $1.052 \pm 0.169$ & $1.172 \pm 0.288$ & $1.373 \pm 0.233$ \\
\hline Probability & 0.899 & 0.536 & 0.121 & 0.468 & 0.696 & 0.765 \\
\hline
\end{tabular}

Table 5. Effect of added sodium chloride level on sensory traits of cooked broiler breast meat (mean \pm SEM) $(n=44$ panelists $)$

\begin{tabular}{cccc}
\hline \hline $\begin{array}{c}\text { Added salt } \\
(\%)\end{array}$ & Tenderness $^{1}$ & Juiciness $^{2}$ & Overall likely $^{3}$ \\
\hline 0.0 & $5.0 \pm 0.31 \mathrm{a}$ & $4.3 \pm 0.31 \mathrm{a}$ & $2.7 \pm 0.19 \mathrm{a}$ \\
0.4 & $4.5 \pm 0.27 \mathrm{a}$ & $4.4 \pm 0.25 \mathrm{a}$ & $3.0 \pm 0.16 \mathrm{ab}$ \\
0.8 & $4.7 \pm 0.30 \mathrm{a}$ & $4.5 \pm 0.23 \mathrm{a}$ & $3.2 \pm 0.16 \mathrm{~b}$ \\
1.2 & $5.0 \pm 0.29 \mathrm{a}$ & $5.0 \pm 0.27 \mathrm{a}$ & $3.5 \pm 0.17 \mathrm{~b}$ \\
1.6 & $6.4 \pm 0.20 \mathrm{~b}$ & $5.7 \pm 0.25 \mathrm{~b}$ & $4.1 \pm 0.15 \mathrm{c}$ \\
2.0 & $6.2 \pm 0.18 \mathrm{~b}$ & $5.7 \pm 0.20 \mathrm{~b}$ & $4.0 \pm 0.16 \mathrm{c}$ \\
\hline Probability & $<0.01$ & $<0.01$ & $<0.01$ \\
\hline${ }^{1}$ from 1 (extremely tough) to 8 (extremely tender) (see table 1). \\
${ }^{2}$ from 1 (extremely dry) to 8 (extremely juicy) (see table 1). \\
${ }^{3}$ from 1 (dislike very much) to 5 (like very much) (see table 1). \\
Means with different letters on the same column within the same \\
effect differ significantly $(P<0.05)$.
\end{tabular}

was detected starting from $0.2 \%$. There appears a similar trend in cooked meat colour, but the effects of salt addition on it are not necessarily dramatic (may be of relatively little practical or industry importance). Overall, these results confirm that gradually increasing salt level up to $2 \%$ decrease the lightness of meat (Swatland and Barbut, 1999). When salt is added to the meat, it reduces water availability on the meat surface, thus reducing light reflection and lightness values. However this effect on meat colour can be also related to the trend observed in meat $\mathrm{pH}$. In fact it is well established that darker meat is associated with higher $\mathrm{pH}$ values (Petracci et al., 2009).

The addition of salt to the meat did not influence the susceptibility to lipid oxidation (Table 4). This means that inclusion of salt up to $2 \%$ did not exert a negative effect on lipid peroxidation which can determine the development of rancid odours and flavours.

Finally, sensory test evidenced higher scores of tenderness and juiciness in meat samples treated with 1.6 and $2.0 \%$ sodium chloride levels as well as overall liking increased as the salt increased from 0 to $2 \%$ (Table 5 ). The result concerning tenderness agrees with the instrumental evaluation previously described (AK-shear force). Moreover panellists were able to detect the positive effect of salt addition on meat palability starting from $0.8 \%$, with the highest overall likely scores attributed to 1.6 and $2.0 \%$ groups. These results confirm the enhancing effect of salt addition on meat flavour and palatability (Barbut, 2002; Alvarado and McKee, 2007) and how it is difficult to reduce salt levels of poultry processed foods without impairing acceptance by consumers (Weiss et al., 2010).

\section{Conclusions}

The results obtained in this study showed that pretreatment with sodium chloride determined a significant modifications of overall quality traits of the frozen broiler breast meat with special regards to $\mathrm{pH}$, colour, water holding capacity and tenderness at even lower concentration of $0.2-0.4 \%$. Increased levels of salt determined a higher $\mathrm{pH}$, darker colour, superior water holding capacity (measured by thaw, drip and cooking losses), and higher tenderness (lower AK-shear values). The maximum improvement of WHC was observed by salt level higher than $1.2 \%$. Sensory test evidenced higher scores of overall preference of meat starting from $0.8 \%$ salt concentration; moreover it was observed higher scores of tenderness, juiciness and overall preference in meat samples having with the higher salt content (1.6 and $2.0 \%$ groups) confirming the well-known positive effect of salt on meat flavour and palatability.

\section{References}

A.O.A.C. Official methods of analysis. Association of Official 
Analytical Chemists, Washington, DC. 1995.

Alvarado $\mathrm{C}$ and McKee S. Marination to improve functional properties and safety of poultry meat. Journal of Applied Poultry Research, 16: 113-120. 2007.

Barbut S. Measuring sensory and functional properties. In: Poultry products processing. An industry guide. pp. 467-511. CRC Press. New York. 2002.

C.I.E. International Commission on Illumination, Recommendations on uniform color space difference equations, Psychrometric color terms. C.I.E. publication, 15 (E-1.3.1) 1971/(TO-1.3) Paris. 1978.

Cavani C, Petracci M, Trocino A and Xiccato G. Advances in research on poultry and rabbit meat quality. Italian Journal of Animal Science 8 (suppl. 2): 741-750. 2009.

Cheng Q and Sun DW. Factors affecting the water holding capacity of red meat products: a review of recent research advances. Critical Reviews in Food Science and Nutrition, 48: 137-159. 2008 .

Desmond E. Reducing salt: A challenge for the meat industry. Meat Science, 74: 188-196. 2006.

Doyle $\mathrm{M}$ and Glass KA. Sodium reduction and its effect on food safety, food quality, and human health. Comprehensive Reviews in Food Science and Food Safety, 9: 44-56. 2010.

Feiner G. Meat products handbook - Practical science and technology. Woodhead Publishing Limited. Cambridge. England. 2006.

Fletcher DL. Further processing of poultry. In: Poultry Meat Processing and Quality (Mead GC ed.). pp. 108-134. CRC Press, Boca Raton, Florida, USA. 2004.

Hamm R. Functional properties of the myofibrillar system and their measurements. In: Muscle as food (Bechtel PJ ed.). pp. 135199. Academic Press Inc. New York, USA. 1986.

James SJ and James C. Meat refrigeration. Woodhead Publishing Limited. Cambridge. England. 2002.

Jeacocke RE. Continuous measurement of the $\mathrm{pH}$ of beef muscle in intact beef carcasses. Journal of Food Technology, 12: 375386. 1977.

Kornburst DJ and Mavis RD. Relative susceptibility of microsomes from lung, heart, liver, kidney, brain, tests to lipid peroxidation. Lipids, 15: 315-322. 1980.

Kotrola NM and Mohyla P. Quality and safety of frozen poultry and poultry products. In: Handbook of frozen food processing and packaging, Second Edition (Sun DW ed.). pp. 325-342. CRC Press. Boca Raton, Florida, USA. 2011.

Lee YS, Saha A, Xiong R, Owens CM and Meullenet J.F. Changes in broiler breast fillet tenderness, water-holding capacity, and color attributes during long-term frozen storage. Journal of Food Science, 73: E162-E168. 2008.

Leygonie C, Britz TJ and Hoffman LC. Impact of freezing and thawing on the quality of meat: review. Meat Science, 91:
93-98. 2012.

Lowry OH, Rosebrough NJ, Farr AL and Randall RJ. Protein measurement with the Folin-Phenol reagents. Journal of Biological Chemistry, 193: 265-275. 1951.

Offer $\mathrm{G}$ and Trinick J. On the mechanism of water holding in meat: the swelling and shrinking of myofibrils. Meat Science, 8: 245-281. 1983.

Offer $\mathrm{G}$ and Knight P. The structural basis of water-holding in meat, In: Developments in meat science-4 (Lawrie RA ed.). pp. 63243. Publ. Elsevier Applied Science. Amsterdam. 1988.

Petracci M, Bianchi M, Betti M and Cavani C. Color variation and characterization of broiler breast meat during processing in Italy. Poultry Science, 83: 2086-2092. 2004.

Petracci M, Bianchi M and Cavani C. The European perspective on pale, soft, exudative conditions in poultry. Poultry Science, 88 : 1518-1523. 2009.

Petracci M and Baéza E. Harmonization of methodologies for the assessment of poultry meat quality features. World's Poultry Science Journal, 68: 137-153. 2011.

Petracci M, Laghi L, Rocculi P, Rimini S, Panarese V, Cremonini MA and Cavani C. The use of sodium bicarbonate for marination of broiler breast meat. Poultry Science, 91: 526-534. 2012.

Ruusunen $\mathrm{M}$ and Poulane E. Reducing sodium intake from meat products. Meat Science, 70: 531-541. 2005.

Sams AR, Janky DM and Woodward SA. Comparison of two shearing methods for objective tenderness evaluation and two sampling times for physical-characteristic analyses of early harvested broiler breast meat. Poultry Science, 69: 348-353. 1990.

SAS Institute. SAS/STAT Guide for Personal Computers. Version 6.03 ed. SAS Institute Inc. Cary, NC. 1988.

Sebranek JG. Basic curing ingredients. In: Ingredients in meat products (Tarté R ed.). pp. 1-24. Springer. New York. USA. 2009.

Sheard PR and Tali A. Injection of salt, tripolyphosphate and bicarbonate marinade solutions to improve the yield and tenderness of cooked pork loin. Meat Science, 68: 305-311. 2004.

Shults GW and Wierbicki E. Effects of sodium chloride and condensed phosphates on the water-holding capacity, $\mathrm{pH}$ and swelling of chicken muscle. Journal of Food Science, 38: 991994. 1973.

Swatland HJ and Barbut S. Sodium chloride levels in comminuted chicken muscle in relation to processing characteristics and Fresnel reflectance detected with a polirimetric probe. Meat Science, 51: 377-381. 1999.

Weiss J, Gibis M, Schuh V and Salminen H. Advances in ingredient and processing systems for meat and meat products. Meat Science, 86: 196-213. 2010. 